\title{
Wybrane analizy geoinformacyjne w badaniach związków budowy geologicznej z rzeźbą terenu Obniżenia Chabówki-Jordanowa
}

\author{
Selected geoinformation analyses in the study of relation between geology and morphology \\ of the Chabówka-Jordanów Depression
}

\author{
Mateusz Szczęch \\ Instytut Nauk Geologicznych, Uniwersytet Jagielloński, Kraków, mateusz.szczech@uj.edu.pl
}

Zarys treści: W pracy przedstawiono wyniki badań związków budowy geologicznej z rzeźbą terenu na obszarze Obniżenia Chabówki-Jordanowa. W badaniach tych wykorzystano oprogramowanie GIS oraz narzędzia, jakie ono oferuje, a także metody teledetekcyjne. Zastosowano również metodę lineamentów na bazie interpretacji zapisu cyfrowego modelu wysokościowego. Badany teren mający pogórską morfologię jest wyraźnie obniżony w stosunku do otaczających go pasm Beskidów, czego dowodzą mniejsze wysokości wzniesień oraz wartości wysokości względnych. Jest to związane z tektoniką podłoża. Decyduje ona o tym, że w obrębie Obniżenia Chabówki-Jordanowa mamy do czynienia z zapadliskiem śródgórskim. Przeprowadzone analizy pozwoliły na stwierdzenie, że grzbiety na tym terenie uformowane są przede wszystkim w gruboławicowych piaskowcach formacji magurskiej, a obniżenia i doliny w utworach starszych reprezentowanych przez łupki i kompleksy piaskowcowo-lupkowe. Kierunek przebiegu głównych grzbietów oraz części dolin w większości dowiązuje do kierunków głównych struktur fałdowych. Wyznaczone lineamenty na ogół pokrywały się z uskokami w terenie. Metoda ta pozwoliła na stwierdzenie, że część dolin rzecznych wykorzystuje uskoki poprzeczne.

Słowa kluczowe: cyfrowy model wysokościowy, GIS, lineament, rzeźba terenu, budowa geologiczna, Obniżenie Chabówki-Jordanowa

\begin{abstract}
This study presents the results of researches on correlation between geological structure and terrain morphology of the Orawa-Jordanów Depression. GIS tools and software, as well as remote sensing methods were used in the investigations. Lineaments method basing on DEM data was applied too. The research area bearing foothill morphology is distinctly depressed from the surrounding it Beskidy ranges. The foothills are characterized by lower high peek and relative highs than the Beskids. Morphology of the Chabówka-Jordanów Depression is associated with tectonic structure. The tectonics determines that Chabówka-Jordanów Depression is intermountain tectonic trough. Completed analysis allowed to conclude, that ridges on this terrain are mainly formed of the thick-bedded sandstones of the Magura Formation, and depressions and valleys are dissected in older rocks represented by shale and sandstone-shale complexes. Directions of the main ridges and valleys are parallel to extensions of the main fold structures. Lineaments marked in studied terrain correlate mainly with faults. The lineaments method allowed to conclude that some of valleys exploit the transverse faults.
\end{abstract}

Key words: digital elevation model, GIS, lineaments, landform, geology, Chabówka-Jardanów Depression

\section{Wstęp}

Budowa twardego geologicznego podłoża jest jednym z najważniejszych elementów mających wpływ na ukształtowanie powierzchni terenu. Dzięki temu w morfologii powierzchni terenu zakodowane są informacje na temat geologicznych struktur podłoża, toteż możemy wykorzystywać tę korelację przy interpretacji i tworzeniu opracowania budowy geologicznej nawet na obszarach o niewielkiej ilości odsłonięć.

W polskiej literaturze karpackiej na fakt istnienia takiej korelacji zwrócił uwagę już pod koniec XIX w. Rehman (1895). Jeszcze na początku XX w. pojawiło się kilka prac, w których sygnalizowano tę zależność, m.in. Romer, Świderski, Łoziński czy też Smoleński (za Jakubowska 1987, Starkel 1972). Szerzej problematyka ta zajmowali się w swoich badaniach Klimaszewski $(1932,1972)$ i Star- 
kel $(1969,1972,1978)$. Również w badaniach geologicznych $\mathrm{w}$ niektórych pracach sygnalizowano i stosowano taką korelację. Szerzej wykorzystywano ją w badaniach metodą lineametów, a także w sporządzaniu niektórych opracowań kartograficznych. Powstanie metody lineamentów związane jest z pojawieniem się zdjęć satelitarnych, kiedy to $\mathrm{z}$ dużym zdziwieniem zaobserwowano na tych zobrazowaniach prostolinijne formy, które nazwano lineamentami (Bażyński, Graniczny 1978). Oprócz zdjęć satelitarnych wykorzystywane są zdjęcia lotnicze oraz cyfrowe modele wysokościowe (CMW, DEM, ang. Digital Model Elevation). Te ostatnie pozwoliły na wyłączenie z obserwacji szaty roślinnej, co ma przy tej metodzie duże znaczenie. Dane CMW są łatwiejsze w interpretacji aniżeli zobrazowania satelitarne i lotnicze, a przez to mniej subiektywne (Ozimkowski 2008). Do opisu morfologii stosowane są metody morfometryczne. Metody te powstały w XIX w., a intensyfikacja ich rozwoju nastąpiła wraz z pojawieniem się wielkoskalowych map topograficznych. Nowoczesne narzędzia, jakie oferuje nam GIS, znacznie uprościły opracowania z użyciem wcześniej wspomnianych metod. Dzięki GIS zarysowały się również nowe ścieżki badawcze, które można zaimplementować w warsztacie geologicznym i geomorfologicznym. Potwierdzeniem tego faktu są coraz liczniejsze prace z wykorzystaniem metod GIS.

\section{Cel pracy}

Jako poligon do przeprowadzenia analiz mających na celu zbadanie zależności między budową geologiczną a morfologią terenu z zastosowaniem metod GIS wybrano Obniżenie Chabówki-Jordanowa ze względu na ciekawą budowę geologiczną oraz rzeźbę tego terenu, a także na słabe jego rozpoznanie, zarówno pod względem geologicznym, jak i geomorfologicznym. Obniżenie Chabówki-Jordanowa ukształtowane jest na obszarze wystąpień podjednostek bystryckiej i raczańskiej płaszczowiny magurskiej. Słabsze zainteresowanie wśród geologów i geomorfologów tym terenem mogło wynikać z faktu, że skoncentrowali swą uwagę na sąsiednich, bardziej eksponowanych obszarach Beskidu Żywieckiego i Beskidu Makowskiego oraz Kotliny Orawsko-Nowotarskiej. Równocześnie nie podjęto próby dokładniejszego uzasadnienia genezy tego wyraźnego obniżenia.

Głównym celem projektu było prześledzenie związków budowy geologicznej z morfologią terenu na Pogórzu Orawsko-Jordanowskim (ryc. 1) w jego zachodniej części zwanej Obniżeniem Chabówki-Jordanowa przy zastosowaniu nowoczesnych narzędzi, zwłaszcza metod GIS. Analizy te miały również przyczynić się do lepszego rozpoznania budowy geologicznej i morfologii omawianego terenu.

\section{Obszar badań}

Wybrany do badań teren występuje pod nazwą Pogórze Orawsko-Jordanowskie w regionalizacji Balona $\mathrm{i}$ in. (1995; ryc. 1). We wcześniejszych regionalizacjach Klimaszewskiego (1972) i Starkla (1972) opisany jest on pod nazwą Bramy Sieniawskiej (jego wschodnia część) oraz Pogórza Orawskiego (w części zachodniej). Do przeprowadzenia analiz wybrano wschodnią część Pogórza Orawsko-Jordanowskiego, która obejmuje swoim zasięgiem Kotlinę Chabówki i Obniżenie Jordanowa z rozdzielającym je Płaskowyżem Naprawy, które łącznie noszą nazwę Obniżenia Chabówki-Jordanowa. Dodatkowo dla lepszego uchwycenia niektórych zależności do badań włączono teren Płaskowyżu Żeleźnicy, Bramy Sieniawskiej, a także południowy fragment Beskidu Makowskiego. Zachodnia

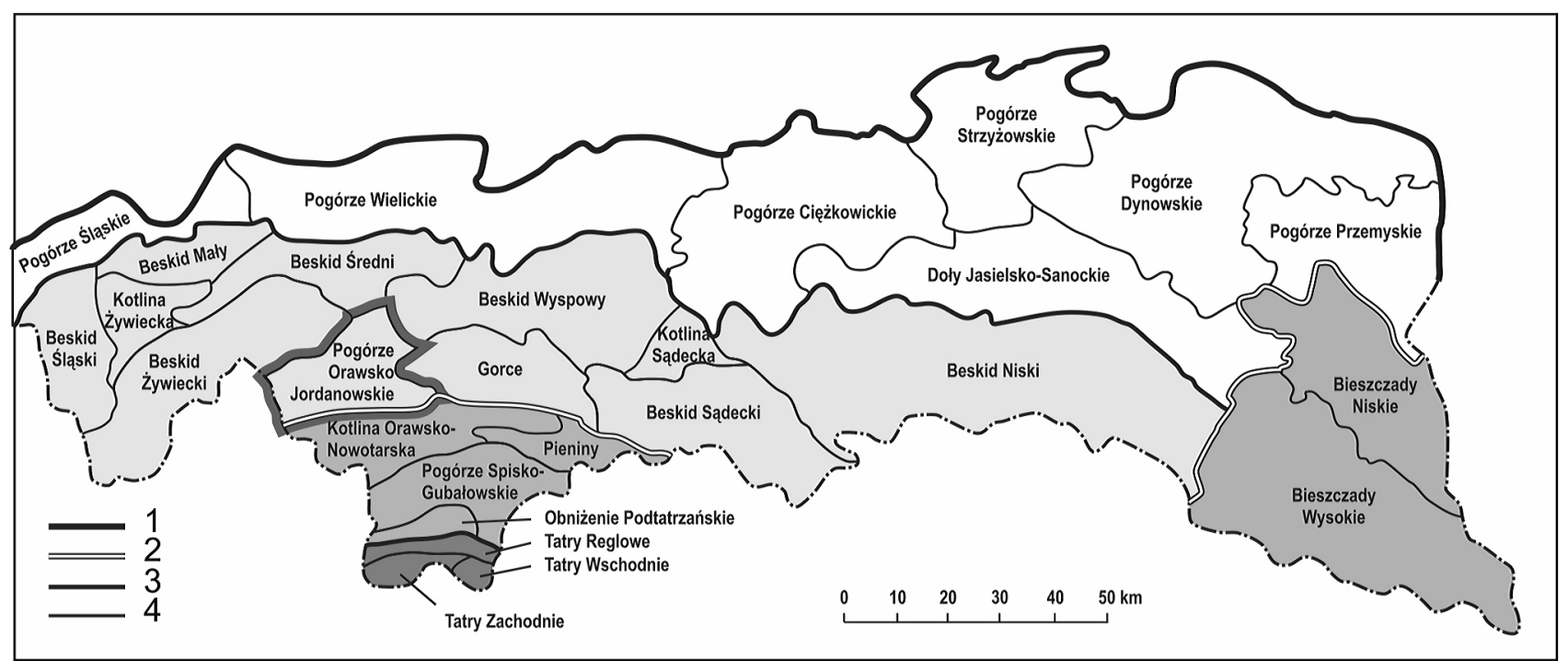

Ryc. 1. Podział fizycznogeograficzny według Balona i in. (1998)

1 - granica prowincji, 2 - granica podprowincji, 3 - granica makroregionów, 4 - granica mezoregionów

Fig. 1. Regions of the Polish Carpathian by Balon et al. (1998)

1 - provinces boundary, 2 - subprovinces boundary, 3 - makroregions boundary, 4 - mezoregions boundary 
granica opracowywanego terenu przebiega wzdłuż głównego europejskiego działu wodnego rozgraniczającego zlewnię Skawy i Raby (zlewisko Bałtyku) od zlewni Czarnej Orawy (zlewisko Morza Czarnego) oraz wzdłuż Pasma Polic. Południowa granica biegnie działem wodnym pomiędzy zlewnią Raby i Dunajca. Północną granicę wyznaczają południowe grzbiety Beskidu Średniego oraz Wyspowego. Od wschodu natomiast teren badań ograniczony jest przez masyw Gorców (ryc. 1).

\section{Budowa geologiczna}

Obniżenie Chabówki-Jordanowa ma ciekawą budowę geologiczną. Jest zbudowane $\mathrm{z}$ górnokredowych i paleogeńskich fliszowych utworów trzech podjednostek płaszczowiny magurskiej: krynickiej, bystrzyckiej i raczańskiej, na których zalegają utwory czwartorzędowe. Utwory płaszczowiny magurskiej deponowane były w basenie magurskim. W obrębie całego basenu magurskiego do wczesnego paleogenu mamy do czynienia $\mathrm{z}$ jednolitymi $\mathrm{w}$ miarę warunkami sedymentacyjnymi (Cieszkowski, Oszczypko 1986). We wczesnym eocenie dochodzi do wyraźnego zróżnicowania warunków sedymentacji w basenie. To właśnie w wyniku tego zróżnicowania w obrębie płaszczowiny magurskiej wyróżniono cztery strefy facjalno-tektoniczne (podjednostki): krynicką, bystrzycka, raczańską i Siar. Trzy pierwsze występują na terenie badań. W miocenie zostały one odkłute od pierwotnego podłoża i nasunięte wraz z całą płaszczowiną ku północy na jednostki przedmagurskie z największą z nich jednostką dukielską (Książkiewicz 1977) oraz na jednostkę śląską. Podczas fałdowania w płaszczowinie magurskiej powstał szereg antyklin oraz synklin, a także wewnętrznych złuskowań. Zarówno w trakcie fałdowań, jak i po nich płaszczowina ta została pocięta uskokami poprzecznymi oraz ukośnymi. To w czasie ruchów fałdowych zindywidualizowały się tektonicznie podjednostki płaszczowiny magurskiej. W powierzchniowym obrazie podjednostki krynickiej dominują utwory piaskowcowe formacji magurskiej (eocen - górny oligocen) reprezentowanej przez ogniwo piaskowców z Piwnicznej, ogniwo z Kowańca oraz ogniwo piaskowców z Popradu. Tylko w kilku miejscach na powierzchni pojawiają się tu piaskowcowo-łupkowe utwory formacji ropianieckiej (kreda górna - paleocen). W podjednostce bystrzyckiej na powierzchni występują utwory łupków pstrych formacji z Łabowej (eocen dolny), piaskowcowo-łupkowej formacji beloweskiej (eocen dolny - eocen środkowy) oraz piaskowcowo-marglistej formacji bystrzyckiej (eocen środkowy). Podjednostka raczańska jest reprezentowana na terenie badań przede wszystkim przez gruboławicowe piaskowce formacji magurskiej wieku eocen górny - oligocen (ok. 3/4 pow.), a także utwory formacji beloweskiej (eocen środkowy i górny) i formacji z Łabowej (eocen dolny) rozciągające się wąskimi pasami. Lokalnie pojawiają się też utwory formacji ropianieckiej. Zarówno w obrębie formacji bystrzyckiej, jak i ropianieckiej występują utwory olistostromowe (Cieszkowski 2007, Cieszkowski i in. 2009, 2010).

\section{Rzeźba terenu}

Pomimo podobnej budowy geologicznej rzeźba terenu w Obniżeniu Chabówki-Jordanowa wyraźnie różni się od rzeźby otaczających go pasm górskich Beskidu Żywieckiego i Beskidu Średniego oraz Gorców. Obniżenie Chabówki-Jordanowa ma znacznie mniejsze wysokości bezwzględne, deniwelacje terenu oraz nachylenia stoków. Na obszarze badań dominują wysokości z przedziału od 500 do 750 m n.p.m. Główny rys morfologii jest tu wynikiem działania procesów zachodzących w pliocenie, kiedy to powstały główne elementy współczesnej rzeźby Karpat zewnętrznych (Paul, Ryłko 1987). W późniejszym okresie mamy do czynienia z postępującymi modyfikacjami rzeźby oraz powstawaniem pokryw osadowych. Współczesna morfologia badanego terenu charakteryzuje się typem rzeźby pogórza średniego oraz wysokiego (Płaskowyż Naprawy, Płaskowyż Żeleźnicy, Brama Sieniawska), a w obrębie Kotliny Chabówki i Obniżenia Jordanowa rzeźbą pogórza niskiego, zaś otaczające je pasma Beskidów oraz Gorców mają charakter rzeźby gór średnich. Zarówno Kotlina Chabówki, jak i Obniżenie Jordanowa zostały porozcinane przez cieki o szerokich płaskodennych dolinach. Grzbiety są tu natomiast bardzo szerokie i zaokrąglone, a nachylenia stoków nie przekraczają zazwyczaj 10\%. W obrębie Płaskowyżu Naprawy rozdzielającego Kotlinę Chabówki od Obniżenia Jordanowa zaznacza się dwupodział rzeźby (Paul, Ryłko 1987). Zachodnia część płaskowyżu charakteryzuje się większymi nachyleniami stoków w stosunku do wschodniej oraz większymi wysokościami wzniesień, przekraczającymi 750 m n.p.m., podczas gdy we wschodniej części wysokości mieszczą się w przedziale 500-600 m n.p.m. Płaskowyż ten rozcinają wąskie doliny o głębokości 150-200 m (Starkel 1972). Płaskowyż Żeleźnicy rozcinają doliny wciosowe do $300 \mathrm{~m}$ (Starkel 1972), natomiast grzbiety są tu najczęściej zaokrąglone. Oddzielony jest on od północy stromym progiem morfologicznym od Kotliny Chabówki. Podobną rzeźbą cechuje się obszar Bramy Sieniawskiej, jednak ma on niższe o około 100-200 m wysokości bezwzględne i łagodnie opada ku północy, w kierunku Kotliny Chabówki. Obniżenie morfologiczne badanego terenu związane jest z tektoniką podłoża, która narzuciła omawianemu Obniżeniu Chabówki-Jordanowa strukturę zapadliska śródgórskiego.

\section{Metodyka}

Do przeprowadzenia analiz zmierzających do rozwiązania problemów zawartych w postawionych w niniejszym projekcie celach wykorzystano następujące materiały: Szczegółową Mapę Geologiczną Polski (SMGP) w skali 1:50 000, w tym arkusze Osielec (Burtan, Szy- 
makowska 1964) oraz Rabka (Paul, Ryłko 1986), cyfrowy model wysokościowy (CMW), wykonany w ramach europejskiego programu Land Parcel Identification System na zlecenie Agencji Restrukturyzacji i Modernizacji Rolnictwa, a także mapę topograficzną w skali 1:25 000. Wszystkie analizy przeprowadzono w aplikacjach ArcGIS10 oraz ErdasImagine 9.3. Istotnym etapem prac było dostosowanie danych cyfrowego modelu wysokościowego do potrzeb analiz. Pierwszym krokiem prac było połączenie 33 arkuszy CMW oraz dobranie odpowiedniej rozdzielczości oczka siatki rastrowej, aby jak najmniej utracić na jakości danych, a jednocześnie zoptymalizować wielkość pliku oraz czas analiz, ponieważ wraz ze zmniejszaniem się rastra wzrasta objętość pliku i czas analiz (Wieczorek, Żyszkowska 2011). W związku z tym wygenerowano 5 obrazów o różnej rozdzielczości map od 5 do $50 \mathrm{~m}$. Ostatecznie wybrano CMW metodą wizualną o rozdzielczości $25 \mathrm{~m}$, jednak, jak podkreśla Olszewski (2009), metoda ta jest obarczona dużym subiektywizmem. Również mapy geologiczne wymagały odpowiedniego przygotowania, zostały one zwektoryzowane, a następnie połączone.

Po etapie wstępnym przystąpiono do właściwych analiz. Rozpoczęto je od utworzenia uproszczonego szkicu morfologicznego analizowanego terenu (ryc. 2), na którym znalazły się linie szkieletowe oraz nachylenia powierzchni terenu. Linie szkieletowe (sieć drenażu oraz grzbiety) utworzono przy użyciu topograficznego współczynnika uwilgotnienia (ang. Topographic Wetness Index TWI), który uwzględnia wilgotność podłoża oraz kierunek spływu. Współczynnik ten został zaprezentowany w publikacji Bevena i Kirkby’ego z 1979 r. (za Kasprzak, Traczyk 2010). Za pomocą TWI oblicza się ilość odpływającej wody $\mathrm{z}$ określonej powierzchni i sumuje się ją. Największe wartości TWI przyjmuje w dolinach, zaś najmniejsze w obrębie grzbietów. Doliny oraz grzbiety wyznaczono poprzez modyfikację współczynnika TWI znajdującą się w dodatku ArcHydro do aplikacji ArcMap 10. Pierwszym etapem prac było utworzenie mapy rastrowej zakumulowanego przepływu. Zakumulowany przepływ opiera się na ilości oczek siatki mapy rastrowej, z których woda spływa do kolejnego oczka (któremu przypisano wartość jeden), w wyniku czego w następnych oczkach siatki w miarę przemieszczania się $\mathrm{w}$ dół stoku oczka przyjmują większe wartości. Największe wartości oczka siatki mapy rastrowej uzyskują w obrębie osi dolin. Potem na podstawie mapy rastrowej skumulowanego przepływu w miejscach największych wartości utworzono sieć drenażu. Natomiast w miejscach, gdzie wartości były zbliżone do 1, wyznaczono przebieg linii grzbietowych. Mapy rastrowe sieci drenażu oraz linie grzbietowe przekształcono w warstwy wektorowe. Ze względu na zbyt dużą gęstość sieci drenażu usunięto z rozważań niewielkie doliny o długości nie przekraczającej na ogół $1 \mathrm{~km}$ oraz doliny suche. Również linie grzbietowe zostały zmodyfikowane poprzez usunięcie grzbietów niższego rzędu oraz uzupełnienie niektórych fragmentów grzbietów głównych. Warstwę wzniesień wygenerowano $\mathrm{w}$ programie ErdasImagine
9.3. W aplikacji tej skonstruowano bardzo prosty model bazujący na najbliższym sąsiedztwie $\mathrm{z}$ użyciem funkcji maksimum lokalnego o wymiarach ruchomego okna 15 $\times 15$ oczek siatki rastrowej. Obliczenia te wykonano na CMW, a dodatkowo przy konstrukcji funkcji przyjęto, że kulminacje terenu są oczkami siatki, w których wartości wszystkich sąsiadujących oczek na określonym obszarze są niższe od wysokości środkowego oczka siatki rastrowej. Jednak do tej funkcji dodano jeszcze jedno założenie: sąsiednie oczka mogą mieć takie same wartości, ponieważ w obrębie niektórych kulminacji kilka sąsiednich oczek miało takie same wartości. Następnie obraz poddano weryfikacji i przekształcono w warstwę wektorową. Ważnym elementem, który umieszczono na szkicu geomorfologicznym, były nachylenia stoków, które obliczono za pomocą narzędzia znajdującego się w aplikacji ArcMap 10, a potem podzielono na 4 klasy (ryc. 2). Efekt finalny analiz prezentuje szkic geomorfologiczny (ryc. 2).

W kolejnych pracach przystąpiono do konstrukcji mapy lineamentów. Metoda ta była polem szerokiej polemiki i, jak zwracają uwagę Graniczny i Mizerski (2003), ważne jest, aby w pracy tak dokładnie zdefiniowano pojęcia lineamentu oraz warsztatu pracy, żeby nie budziły one wątpliwości wśród krytyków tej metody. Tak więc prace rozpoczęto od zdefiniowania lineamentu. Za morfolineamenty uznano te elementy liniowe widoczne w morfologii terenu, które odpowiadały definicji O'Leary i in. (1976) - ,możliwa do zinterpretowania cecha liniowa powierzchni (lub ich kompozycje) zorientowana w całości lub na pewnych odcinkach prostoliniowo i odzwierciedlająca prawdopodobnie pewne zjawiska w podłożu" (za Chodyń 2004). W zależności od skali materiałów, jakie wykorzystywane są do przeprowadzenia analiz, możemy uzyskać różne lineamenty odpowiadające różnym typom struktur geologicznych. Na zobrazowaniach małoskalowych otrzymujemy informacje na temat struktur regionalnych bądź kontynentalnych, które w rzeczywistości są systemami struktur, natomiast $\mathrm{w}$ dużych skalach otrzymujemy informacje na temat struktur lokalnych. Dodatkowo w zależności od skali lineamenty mogą być widoczne lub nie bądź te same struktury mogą składać się z jednego lub kilku lineamentów (Ollier 1987). Lineamenty wyznaczono na podstawie CMW w dużej skali, aby uchwycić lineacje związane z pojedynczymi strukturami podłoża. $\mathrm{Na}$ podstawie CMW wygenerowano numeryczny model terenu (NMT) przedstawiający cieniowaną jego rzeźbę, który poprzez zmiany intensywności barwy miał za zadanie uwypuklić cechy morfologiczne analizowanego obszaru. W zależności od danych, jakie zostały wykorzystane do wyznaczenia lineamentów, możemy mówić o fotolineamentach - gdy wyrysowane są na podstawie zmienności fototonu, bądź topolineamentach - wydzielonych na podstawie map (Zuchiewicz 2010). Przy wyznaczaniu lineamentów, które mogą mieć związek ze strukturami tektonicznymi, kierowano się wcześniej przyjętymi założeniami wynikającymi bezpośrednio z przyjętej definicji. Fotolineamenty wyznaczano na podstawie prostolinijnych odcinków dolin rzecznych, krawędzi morfologicznych, 
miejsc z wyraźnym przemieszczeniem lub skrętem linii grzbietowych oraz ich kombinacji. Wyznaczone w ten sposób linie można utożsamiać z miejscami przecięcia się $\mathrm{z}$ powierzchnią morfologiczną terenu strukturalnej powierzchni uskoków oraz nasunięć bądź mogą one być wynikiem zmiany odporności podłoża (ryc. 2). Procedurę wyznaczania lineamentów przeprowadzono dwukrotnie w celu zmniejszenia subiektywizmu metody, a następnie skonfrontowano je i naniesiono na jeden arkusz. Ogółem na badanym terenie wyznaczono 270 lineamentów, przy czym wiele $\mathrm{z}$ nich tworzyło większe systemy lineacji, których długość wynosiła 5000-8500 m. Niektóre z nich poddano weryfikacji podczas badań terenowych.

W celu łatwiejszej identyfikacji struktur geologicznych na Szczegółowej Mapie Geologicznej Polski w skali 1:50 000, arkusze Rabka (Paul, Ryłko 1986) oraz Osielec (Burtan, Szymakowska 1964), sporządzono mapę tektoniczną zawierającą informacje na temat przebiegu osi synklin i antyklin, linii nasunięć oraz wewnętrznych złuskowań, a także uskoków. Struktury fałdowe oraz nasunięcia i złuskowania są zakodowane pośrednio w obrazie mapy geologicznej poprzez symbole parametrów zalega-

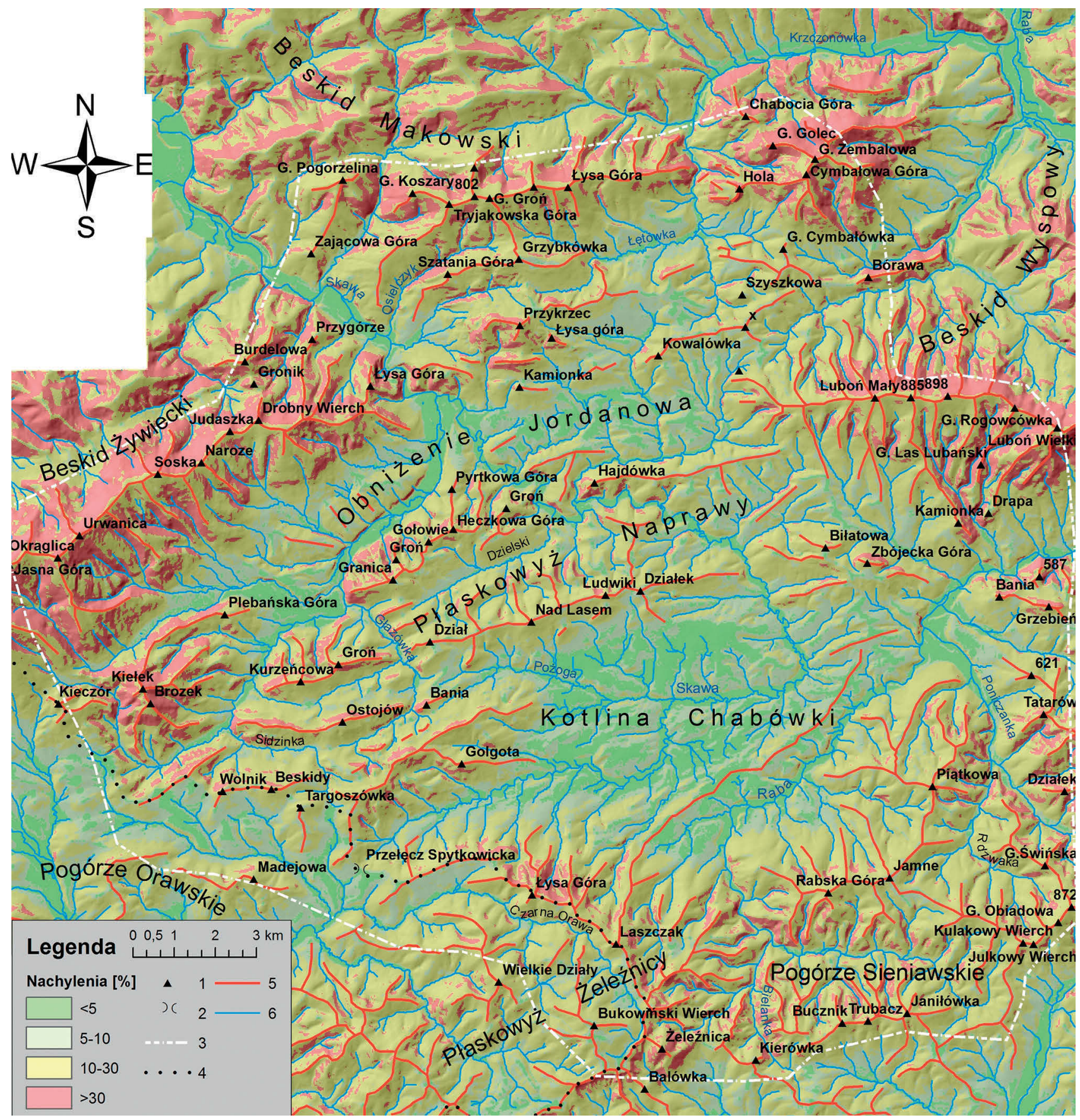

Ryc. 2. Szkic geomorfologiczny Obniżenie Chabówki-Jordanowa

1 - szczyty, 2 - przełęcze, 3 - teren badań, 4 - europejski dział wodny, 5 - grzbiety, 6 - doliny

Fig. 2. Geomorphological sketch map of Chabówka-Jordanów Depression

1 - peeks, 2 - mountain pass, 3 - research area, 4 - European Watershed, 5 - ridges, 6 - valleys. 
nia warstw oraz ułożenie wydzieleń jednostek litostratygraficznych. Dodatkowo na podstawie symboli zalegania warstw możemy ustalić ułożenie oraz geometrię synklin i antyklin. Symbole parametrów zalegania w antyklinie wyznaczają przeciwstawne kierunki zapadania warstw w jej skrzydłach, a w synklinie kierunki zbieżne. Posługując się wyżej wymienionymi prawidłowościami można wyznaczyć osie synklin i antyklin. Na podstawie następstwa warstw możemy zgodnie z zasadami wydzielić struktury fałdowe - jeżeli wewnątrz mamy do czynienia z utworami najstarszymi, jest to antyklina, natomiast w jądrze synkliny mamy do czynienia $z$ utworami najmłodszymi. Linie nasunięć w obrazie mapy są widoczne dzięki redukcji występowania warstw - utwory młodsze kontaktują się wprost z utworami starszymi, brak natomiast utworów pośrednich. Dzięki temu możliwe jest wyznaczenie nasunięć i złuskowań. Uskoki są widoczne na mapach geologicznych przez to, że ich występowaniu towarzyszy przerwanie ciągłości warstw. Konstruowaną mapę tektoniczną uzupełniono dodatkowo o dane pochodzące $\mathrm{z}$ metody lineamentów i naniesiono na nią te lineamenty, które po wnikliwej analizie uznano za związane z uskokami (ryc. 4). Interpretacja tektoniki dokonana przez autora nieco odbiega od interpretacji zawartych w objaśnieniach do arkuszy Rabka (Paul, Ryłko 1987) i Osielec (Wójcik, Rączkowski 1994). W niektórych punktach autor nie zgadzał się $\mathrm{z}$ interpretacją tektoniki powyższych autorów,
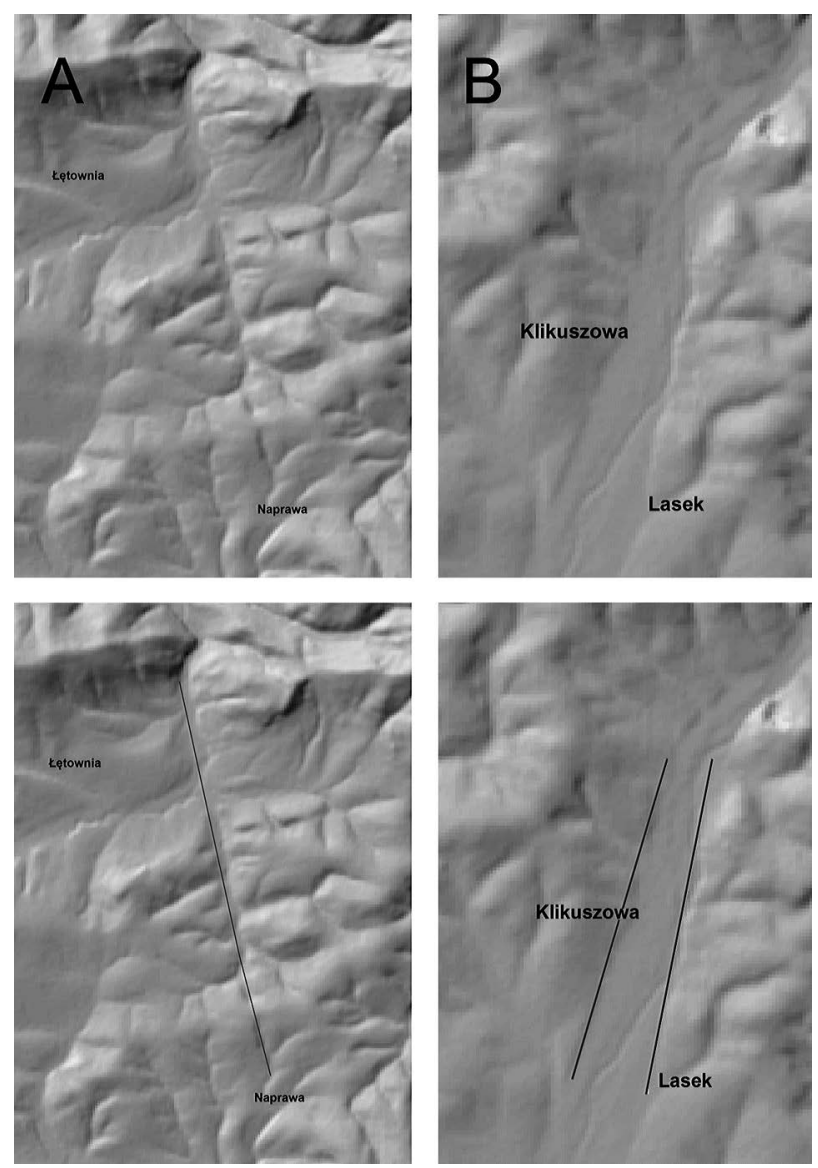

Ryc. 3. Przykłady lineamentów widocznych na CMW

Fig. 3. Examples of lineaments visible on the DEM toteż na mapie tektonicznej uwzględnił wyniki własnych interpretacji uzyskanych dzięki wnikliwej analizie istniejących materiałów geologiczno-kartograficznych i analizie lineamentów. W trakcie wnikliwej analizy CMW zidentyfikowano nowe uskoki, m.in.: uskoki w dolinie potoku Lepietnica w rejonie wsi Lasek i Klikuszowa, system dyslokacji Kojszówki, uskok Naprawy-Łętowni czy też uskok Targoszówki-Kurzeńcowej. W dalszej kolejności udało się uściślić typ oraz przebieg już wcześniej wyznaczonych uskoków przez wspomnianych wyżej autorów, a w tym południowej części uskoku Łętowni-Górnej Skawy, który tak naprawdę składa się z systemu uskoków kulisowych. Nadto stwierdzono, że uskok Rokiciny-Lasek znaczony na mapie Paul i Ryłko (1987) jedną liną jest zespołem mniejszych uskoków. Poczynione w trakcie tych analiz obserwacje znalazły w późniejszym czasie potwierdzenie w trakcie kontrolnych badań terenowych, podczas których autor stwierdzał $\mathrm{w}$ terenie $\mathrm{w}$ miejscach wcześniej wyznaczonych lineamentów różne zjawiska towarzyszące uskokom, takie jak: fragmenty powierzchni uskokowych z systemami rys i zadziorów tektonicznych, brekcje tektoniczne, zagęszczenia sieci spękań, a w szczególnych przypadkach obfitość wystąpień żył kalcytowych wypełniających szczeliny spękań.

Po otrzymaniu szkicu geomorfologicznego (ryc. 2) oraz mapy tektonicznej (ryc. 4) przystąpiono do prześledzenia głównych prawidłowości w morfologii analizowanego terenu, a także udzielenia odpowiedzi na pytanie, jaki ma ona związek z geologią podłoża. Otrzymane wcześniej mapy i szkice nakładano na siebie w aplikacji ArcMap 10 i poddawano je ocenie wizualnej. W ocenie stopnia odporności skał podłoża przyjęto pewne uproszczenie, które przedstawiono w tabeli 1 ilustrującej odporności skał poszczególnych jednostek litostratygraficznych.

\section{Wyniki badań}

W trakcie studiów porównawczych w pierwszej kolejności starano się ocenić stopień korelacji rzeźby z budową geologiczną badanego terenu. W rejonie badań odporność skał pociąga za sobą powstanie określonych form ukształtowania powierzchni. Na obszarze Pogórza Orawsko-Jordanowskiego najważniejsze grzbiety uformowane są głównie w gruboławicowych piaskowcach formacji magurskiej, natomiast obniżenia i doliny w utworach starszych, reprezentowanych przez łupki i piaskowcowo-łupkowe kompleksy fliszowe. Dodatkowo w strefach występowania odpornych piaskowców magurskich mamy do czynienia z dużymi spadkami terenu. W obrębie grzbietów, gdzie występują utwory mniej odporne, powstają obniżenia i przełęcze, czego przykładem jest położona pomiędzy wsiami Spytkowice i Podwilk, obok drogi krajowej S7, Przełęcz Spytkowicka (701 m n.p.m.), która założona jest na bardziej podatnych na erozję utworach formacji beloweskiej. Główne grzbiety i część dolin cieków w obrębie Obniżenia Chabówki-Jordanowa 


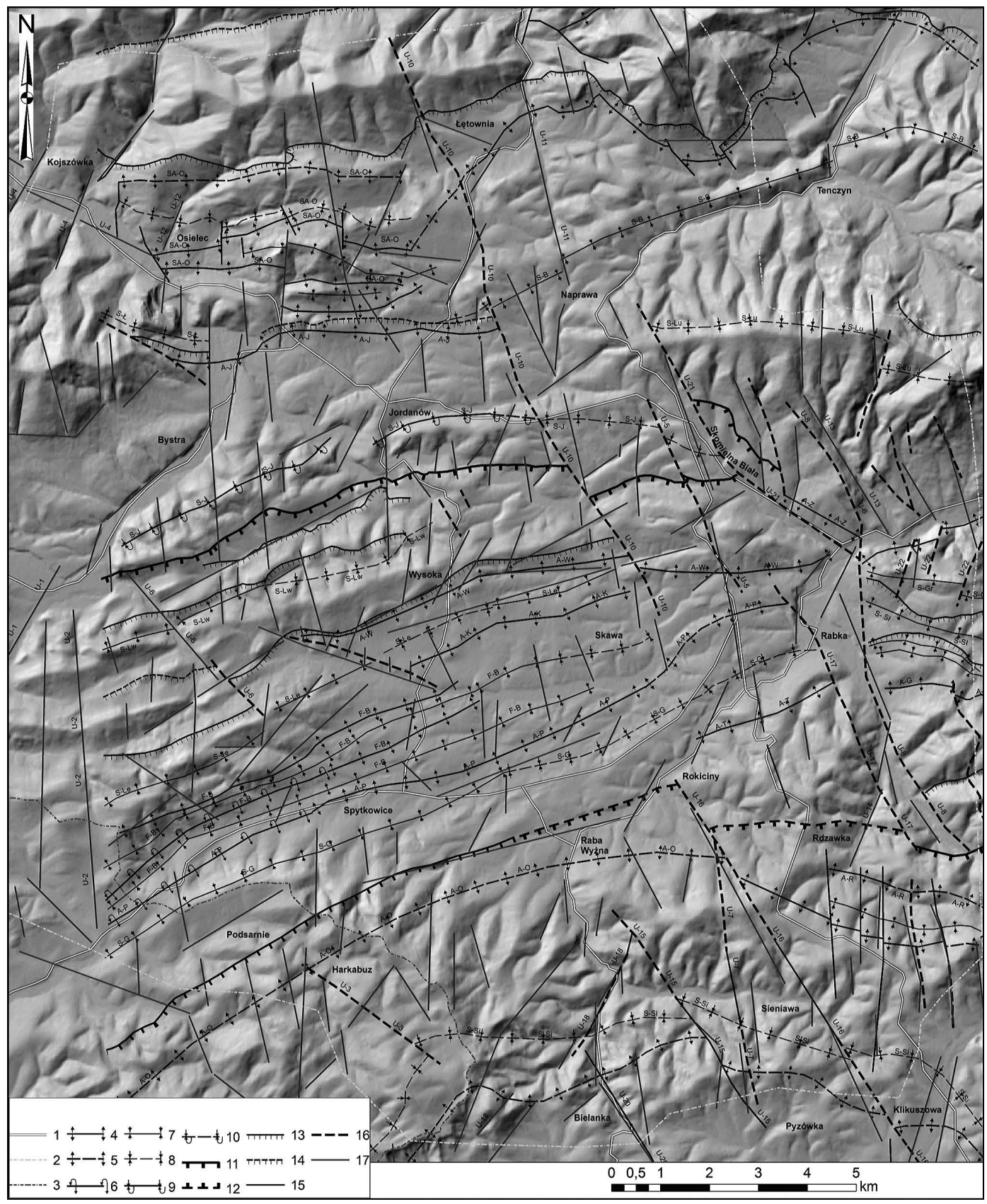

Ryc. 4. Mapa tektoniczna wraz z lineamentami

1 - drogi, 2 - granice terenu badań, 3 - europejski dział wodny, 4 - oś antykliny, 5 - oś antykliny przypuszczalnej, 6 - oś antykliny odwróconej, 7 - oś synkliny, 8 - oś synkliny przypuszczalnej, 9 - oś synkliny odwróconej, 10 - oś synkliny odwróconej przypuszczalnej, 11 - nasunięcie podjednostki, 12 - nasunięcie podjednostki przypuszczalne, 13 - łuska, 14 - łuska przypuszczalna, 15 - uskok, 16 - uskok przypuszczalny, 17 - lineamenty, U-1 - uskok Sidzinki, U-2 - uskok Targoszówki-Kurzeńcowej, U-3 - uskok Podszkla, U-4 - system dyslokacyjny Kojszówki, U-5 - uskok Birłatowej, U-6 - uskok Głazówki, U-7 - uskok Jamnego, U-8 - uskok Kamionki-Gawronówki, U-9 - uskok Łetowni, U-10 - uskok Łetowni-Górnej Skawy, U-11 - uskok Naprawy-Łetowni, U-12 - uskok Osielczyka, U-13 - uskok Potoku Lubońskiego, U-14 - uskok Potoku Rdzawka, U-15 - uskok Raba Wyżna-Krauszów, U-16 - uskok Rokiciny-Lasek, U-17 - uskok Zaborni-Poniczanki, U-18 - uskok Żeleźnicy, U-19 - uskok Łętowni, U-20 - uskok Odrowąż-Bielanka, U-21 - uskok Skomielnej Białej i Birłatowej, U-22 - zespół uskoków Grzebienia, U-23 - uskok Tokarni, A-G - antyklina Gorzkiego, A-J - antyklina Jastrzębika-Malejówki, A-K - antyklina Koskówki, A-O - antyklina Orawki-Łysej Góry-Sośniakówki-Rokicin, A-P - antyklina Podwilka-Spytkowic-Zaborni, A-R - antyklina Rdzawki, A-T - antyklina Tatarów, A-W - antyklina Wysokiej, A-Z - antyklina Zarytego, SA-O - struktura antyklinalna Osielca, S-B - synklina Burawy, S-G - synklina Gronia-Podlesia-Kasinówki-Chabówki, S-Gr - synklina Grzebienia, S-J - synklina Jordanowa, S-Le - synklina Leśniakówki, S-Lu - synklina Lubonia, S-Lw - synklina Ludwików-Wysokiej Dolnej, S-Ł - synklina Łysej Góry, S-Si - synklina Sieniawy, S-Sł - synklina Słonki, F-B - zespół fałdów Brandysówki, F-T - zespół fałdów Toporzyska-Wysokiej Dolnej

Fig. 4. Tectonic map with lineaments

1 -roads, 2 - research area, 3 - European Watershed, 4 - axis of anticline, 5 - axis of probable anticline, 6 - axis of overturned anticline, 7 -axis of syncline, 8 - axis of probable syncline, 9 - sxis of overturned syncline, 10 - axis of probable overturned syncline, 11 - thrust subunit, 12 - probable thrust subunit, 13 - thrust sheet, 14 - probable trust sheet, 15 - faults, 16 - probable faults, 17 - lineaments, U-1 Sidzinka Fault, U-2 Targoszówka-Kurzeńcowa Fault, U-3 Podszkle Fault, U-4 Kojszówka Dislocation System, U-5 Birłatowa Fault, U-6 Głazówka Fault, U-7 Jamne Fault, U-8 Kamionka-Gawronówka Fault, U-9 Łętownia Fault, U-10 Łętownia-Górna Skawa Fault, U-11 Naprawa-Lętownia Fault, U-12 Osielczyk Fault, U-13 Potok Luboński Fault, U-14 Potok Rdzawka Fault, U-15 Raba Wyżna-Krauszów Fault, U-16 Rokiciny-Lasek Fault, U-17 Zabornia-Poniczanka Fault, U-18 Żeleźnica Fault, U-19 Łętownia Fault, U-20 Odrowąż-Bielanka Foult, U-21 Skomielna Biała-Birłatowa Fault, U-22 Grzebień Fault group, U-23 Tokarnia Fault, A-G Gorzkie Antycline, A-J Jastrzębik-Malejówka Antycline, A-K Koskówka Antycline, A-O Orawka-Łysa Góra-Sośniakówka-Rokiciny Antycline, A-P Podwilk-Spytkowice-Zabornia Antycline, A-R Rdzawka Antycline, A-T Tatarów Antycline, A-W Wysoka Antycline, A-Z Zaryte Antycline, SA-O Osielec Antycline structure, S-B Burawa Syncline, S-G Groń-Podlesie-Kasinówka-Chabówka Syncline, S-Gr Grzebień Syncline, S-J Jordanów Syncline, S-Le Leśniakówka Syncline, S-Lu Luboń Syncline, S-Lw Ludwików-Wysoka Dolna Syncline, S-Ł Łysa Góra Syncline, S-Si Sieniawa Syncline, S-Sł Słonka Syncline, F-B Brandysówka faults group, F-T Toporzysko-Wysoka Dolna faults group 
Tabela 1. Odporność utworów poszczególnych jednostek litostratygraficznych występujących na terenie badań

Table 1. Resistance of deposits of lithostratigraphic units occurring in research terrain.

\begin{tabular}{|c|c|}
\hline $\begin{array}{l}\text { Odporność skał } \\
\text { na erozję }\end{array}$ & Jednostka litostratygraficzna \\
\hline duża & $\begin{array}{l}\text { formacja magurska: ogniwo piaskowców z Piwnicznej, ogniwo z Kowańca, ogniwo piaskowców z Popradu; } \\
\text { ogniwo piaskowców osieleckich, ogniwo piaskowce pasierbieckich }\end{array}$ \\
\hline średnia & formacja ropianiecka, formacja bystrzycka (margle łąckie) \\
\hline mała & $\begin{array}{l}\text { formacja łupków z Malinowej (łupki pstre), formacja łupków z Łabowej (pstre łupki), formacja beloweska } \\
\text { (w tym warstwy hieroglifowe) }\end{array}$ \\
\hline
\end{tabular}

oraz terenów przyległych nawiązują swym kierunkiem przede wszystkim do rozciągłości wychodni geologicznych jednostek litostratygraficznych, przyjmując kierunki zgodne z orientacją struktur fałdowych. W zachodniej części struktury jest to orientacja NE-SW, a w kierunku wschodnim skręcają na WNW-ESE (ryc. 2, 4). Są jednak również takie miejsca, gdzie trudno jest zaobserwować korelację morfologii terenu $\mathrm{z}$ odpornością podłoża (Płaskowyż Żeleźnicy, Brama Sieniawska) czy strukturami fałdowymi (Płaskowyż Żeleźnicy).

Ze względu na odporność skał podłoża oraz charakter morfologii, teren badań podzielono na trzy części, w których linie szkieletowe w różnym stopniu korelują z odpornością podłoża oraz strukturami fałdowymi. Pierwsza z nich to strefa północna obejmująca swoim zasięgiem Beskid Makowski oraz Beskid Wyspowy, a także północny fragment Obniżenia Jordanowa. Pokrywa się ona $\mathrm{z}$ zasięgiem podjednostki raczańskiej płaszczowiny magurskiej. W tej to części doliny, m.in. Skomielnianki, Łętowianki czy Walczakówki, wycięte są w mało odpornych utworach lupków pstrych formacji z Łabowej oraz formacji beloweskiej. Grzbiety są natomiast założone w odpornych, piaskowcowych utworach formacji magurskiej. Jest to jednocześnie strefa z największymi spadkami terenu. Druga strefa, centralna, obejmuje swoim zasięgiem Obniżenie Chabówki-Jordanowa i pokrywa się z wychodniami wydzieleń litostratygraficznych wchodzących w skład podjednostki bystrzyckiej, która reprezentowana jest na powierzchni przede wszystkim przez utwory formacji bystrzyckiej oraz formacji beloweskiej. W strefie tej zaznacza się taka prawidłowość, że kulminacje zbudowane są z margli łąckich (reprezentujących formację bystrzycką), np. Zbójecka Góra $644 \mathrm{~m}$ czy Bania $648 \mathrm{~m}$, jednakże w rejonie tym margle tworzą niewysokie, kopulaste wzniesienia, gdyż nie są one tak odporne jak gruboławicowe piaskowcowe. W miejscach wychodni na powierzchnię utworów formacji beloweskiej tworzą się doliny oraz obniżenia, tak jak np. w źródłowym odcinku Skawy w Spytkowicach. Dzieje się tak, ponieważ utwory formacji beloweskiej są znacznie mniej odporne na erozję od utworów formacji bystrzyckiej. Dodatkowo w obrębie Kotliny Chabówki oraz Obniżenia Jordanowa dominują tereny płaskie lub o niewielkim nachyleniu (ryc. 2). W części południowej analizowanego terenu, obejmującej Płaskowyż Żeleźnicy oraz Pogórze Sieniawskie, która pokrywa się z zasięgiem podjednostki krynickiej płaszczowiny magurskiej, brak wyraźniejszej zależności morfologii od odporności podłoża, co wynika z małego zróżnicowania litologicznego skał podłoża. Dominują tu bowiem odporne piaskowce formacji magurskiej, a tylko sporadycznie występują utwory miękkie w postaci głównie łupków pstrych. Teren ten zbudowany jest przede wszystkim z utworów formacji magurskiej reprezentowanej przez ogniwo piaskowców z Piwnicznej oraz ogniwo piaskowców z Kowańca. W utworach tych założone są zarówno doliny, jak i grzbiety. Istotnym elementem modyfikującym rzeźbę terenu są linie nieciągłości - uskoki. W obrębie stref uskokowych dochodzi do osłabienia ośrodka skalnego poprzez powstanie większej ilości spękań oraz brekcji tektonicznych. Miejsca takie stają się bardziej podatne na erozję, a to skutkuje szybszą erozją, zwłaszcza rzeczną, i dlatego często są one wykorzystywane przez cieki powierzchniowe. W miejscach takich dochodzi do zwiększenia się nachyleń zboczy nawet do ponad 30\%, np. odcinek Skawy w Jordanowie, Rzepeczówce oraz w Osielcu.

Analizy wykazały również istnienie związku pomiędzy kierunkiem przebiegu struktur fałdowych z liniami szkieletowymi. Wyjątkiem jest tutaj Płaskowyż Żeleźnicy. W obrębie tego regionu główne grzbiety w morfologii tworzą koncentryczne formy, natomiast najważniejsze doliny odwadniające ten teren, takie jak Orawka czy Bukowski Strumyk, mają poprzeczny bieg dolin (NW) w stosunku do struktur fałdowych (NE-SW; ryc. 2, 4). $\mathrm{Na}$ analizowanym terenie zaznacza się wyraźnie zmiana kierunku przebiegu głównych struktur fałdowych, co pociąga za sobą zgodną zmianę kierunków grzbietów. W zachodniej części przyjmują one kierunek NE-SW, a następnie w centralnej części skręcają na WNW-ESE i tak ciągną się dalej na wschód. Główne doliny natomiast nawiązują do struktur fałdowych tylko na niektórych odcinkach. Analiza lineamentów oraz struktur tektonicznych przedstawionych na rycinie 4 uwidoczniła, że duża część koryt głównych cieków nie nawiązuje do przebiegu struktur fałdowych, co jest spowodowane przez występowanie licznych uskoków poprzecznych. Uskoki te są wykorzystywane również przez boczne dopływy, czego przykładem mogą być cieki na południowych zboczach pasma Lubonia Wielkiego (1022 m). Część tych uskoków została wyznaczona metodą lineamentów, w tym np. odcinki przełomowe doliny Skawy (ryc. 5, 8). W obrębie terenu badań stwierdzono występowanie szeregu uskoków przesuwczych, zrzutowych i zrzutowo-przesuwczych, które wpłynęły na kształtowanie się jego morfologii. 


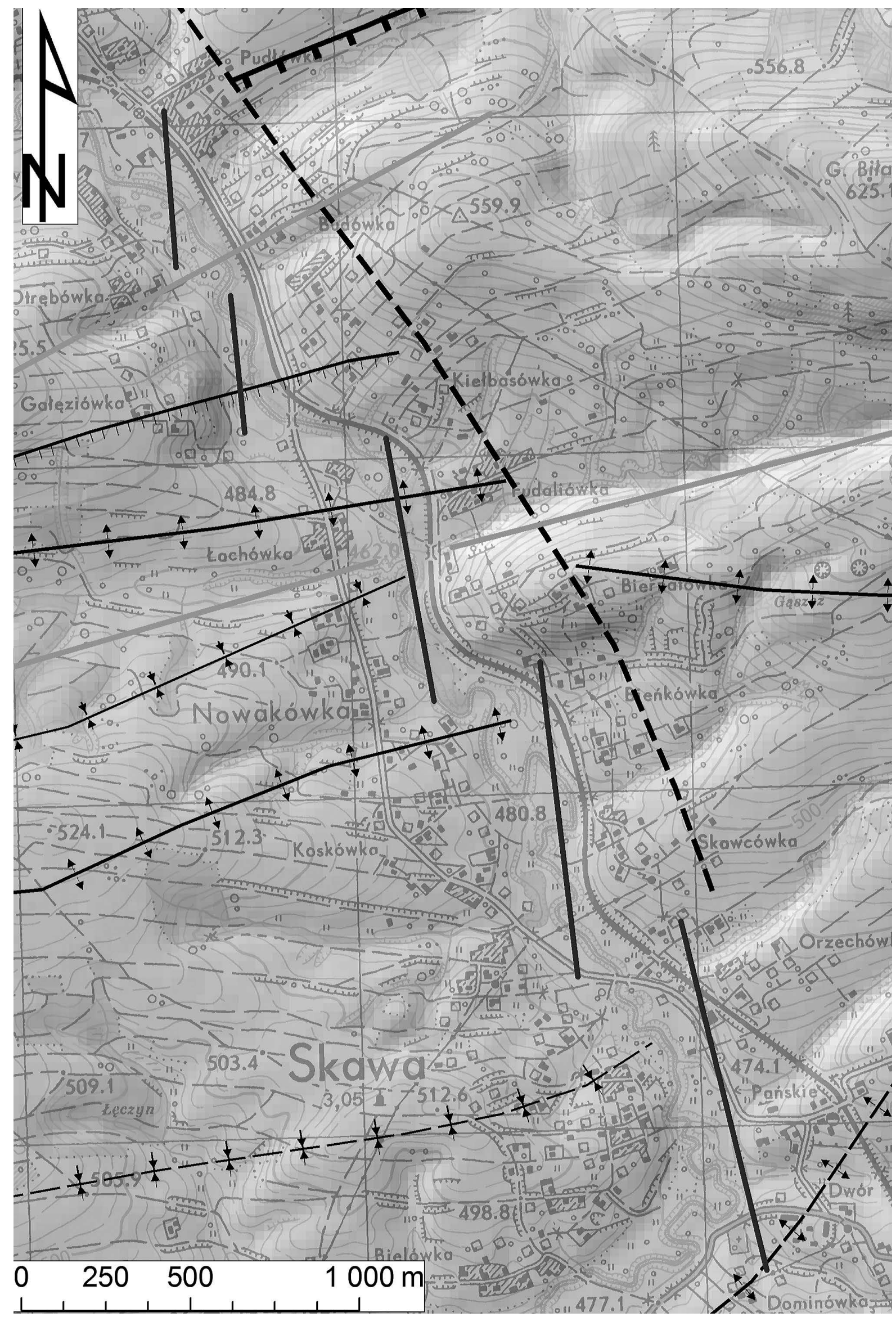

Ryc. 5. Uskoki kulisowe doliny Skawy w obrębie Płaskowyżu Naprawy

Fig. 5. Echelon faults of Skawa river valley in Naprawa Foothills 
Większość uskoków ma przebieg poprzeczny lub ukośny w stosunku do struktur fałdowych. Wśród takich uskoków wyznaczonych w analizie lineamentów dominuje kierunek NW-SE. Z uskokami poprzecznymi związane jest powstanie wielu form morfologicznych, w tym takich jak wcześniej wspomniane odcinki przełomowe rzek oraz zmiany kierunku dolin, a także przesunięcia osi grzbietów i powstawanie $\mathrm{w}$ ich obrębie obniżeń oraz przełęczy (m.in. Przełęcz Sieniawska, Przełęcz Pieniążkowicka).

Analiza danych ze starszych map geologicznych oraz zinterpretowanych przez autora na bazie lineamentów uskoków wskazuje, że Obniżenie Chabówki-Jordanowa jest ograniczone uskokami i ma założenia tektoniczne. Dane te są potwierdzeniem wcześniejszych hipotez stawianych przez badaczy zajmujących się tym terenem (Książkiewicz 1971, Klimaszewski 1972, Paul, Ryłko 1987), że obszar Pogórza Orawsko-Jordanowskiego, a zwłaszcza jego część wschodnia, został tektonicznie obniżony w stosunku do otaczających go pasm Beskidów. Z obniżeniem tektonicznym związany jest pogórski charakter rzeźby Obniżenia Chabówki-Jordanowa. Obniżenie to od wschodu ograniczone jest uskokami o kierunku SSE-NNW, natomiast od zachodu uskokami o kierunku SSW-NNE. Informacje o takich kierunkach uskoków pojawiają się w opracowaniach wielu badaczy (m.in. Zuchiewicz 2010). Geometria lineamentów utożsamianych bezpośrednio z uskokami wskazuje, że Kotlina Chabówki jest zapadliskiem o charakterze obniżenia międzyprzesuwczego (pull-apart). Podobną genezę najprawdopodobniej ma Obniżenie Jordanowa, aczkolwiek jest ono bardziej złożone strukturalnie. Hipotezę o istnieniu obniżenia międzyprzesuwczego w obrębie terenu badań autor oparł na charakterystycznym, romboidalnym układzie uskoków obrzeżających Kotlinę Chabówki oraz Obniżenie Jordanowa. O możliwości istnienia podobnych obniżeń tego typu, aczkolwiek mniejszych, z dolnej części doliny Skawy sygnalizowali Cieszkowski i in. (2006). Dodatkowym potwierdzeniem były badania geodezyjne wykonywane w latach 2004-2006 pod kierownictwem Łoja (za Zuchiewicz 2010). Stacje pomiarowe były umieszczone na terenie Kotliny Orawsko-Nowotarskiej oraz w południowej części Obniżenia Chabówki. Wykazały one przemieszczenie się reperów zainstalowanych w obrębie Płaskowyżu Żeleźnicy przeciwnie do reperów umieszczonych w Kotlinie Chabówki.

\section{Wnioski}

Analizy przeprowadzone na CMW oraz mapie geologicznej są wstępem do dalszych badań nad możliwościami wdrożenia metod GIS i teledetekcyjnych do warsztatu geologicznego na szerszą skalę. Przedstawiona w niniejszym artykule ścieżka badawcza pokazała, że zasadne jest wykorzystanie analiz bazujących na CMW, których

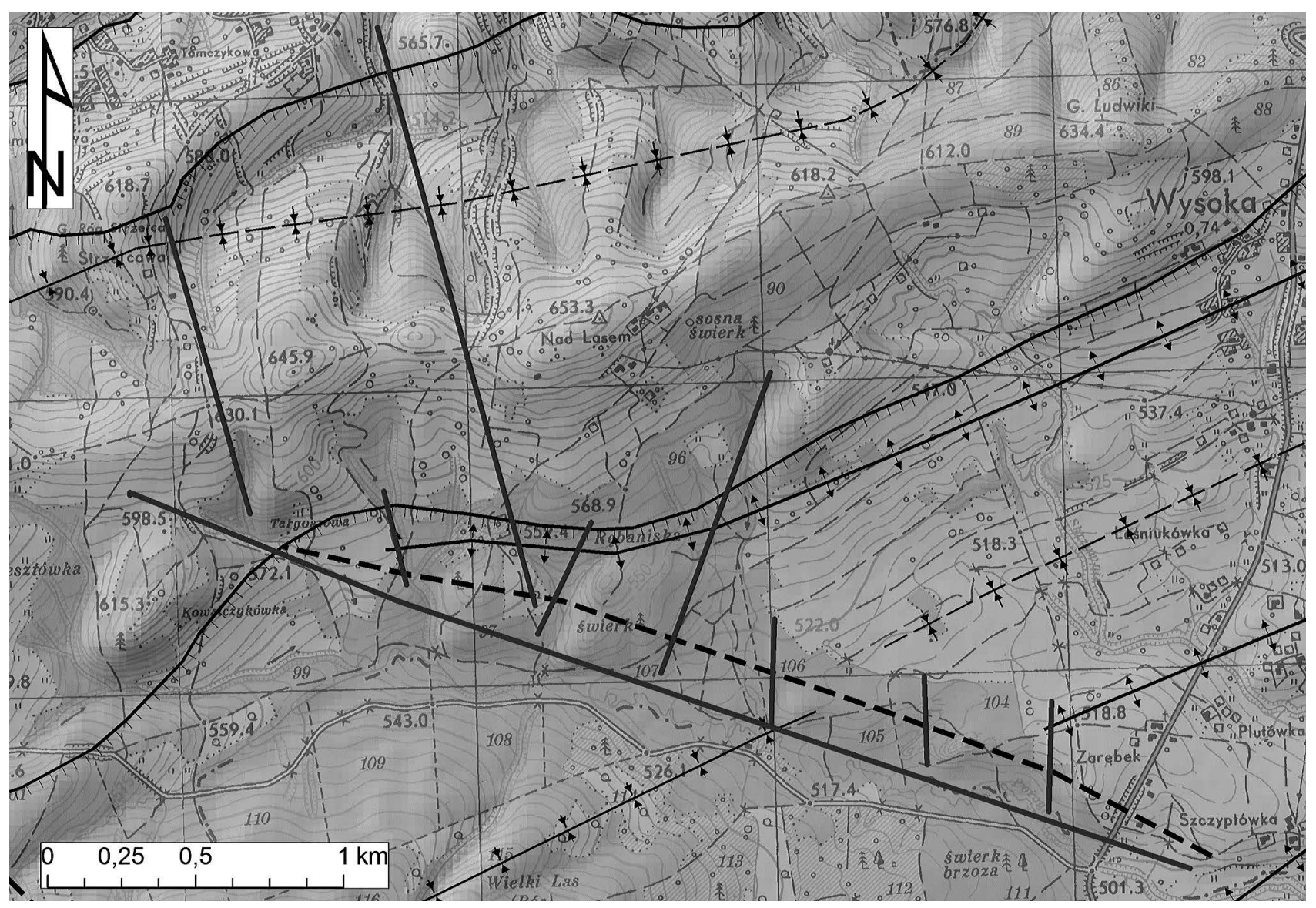

Ryc. 6. System uskoków pierzastych w dolinie potoku Pożoga wyznaczonych z zastosowaniem metody lineamentów

Fig. 6. Feathery fault system in Pożoga creek valley marked with using of lineaments method 


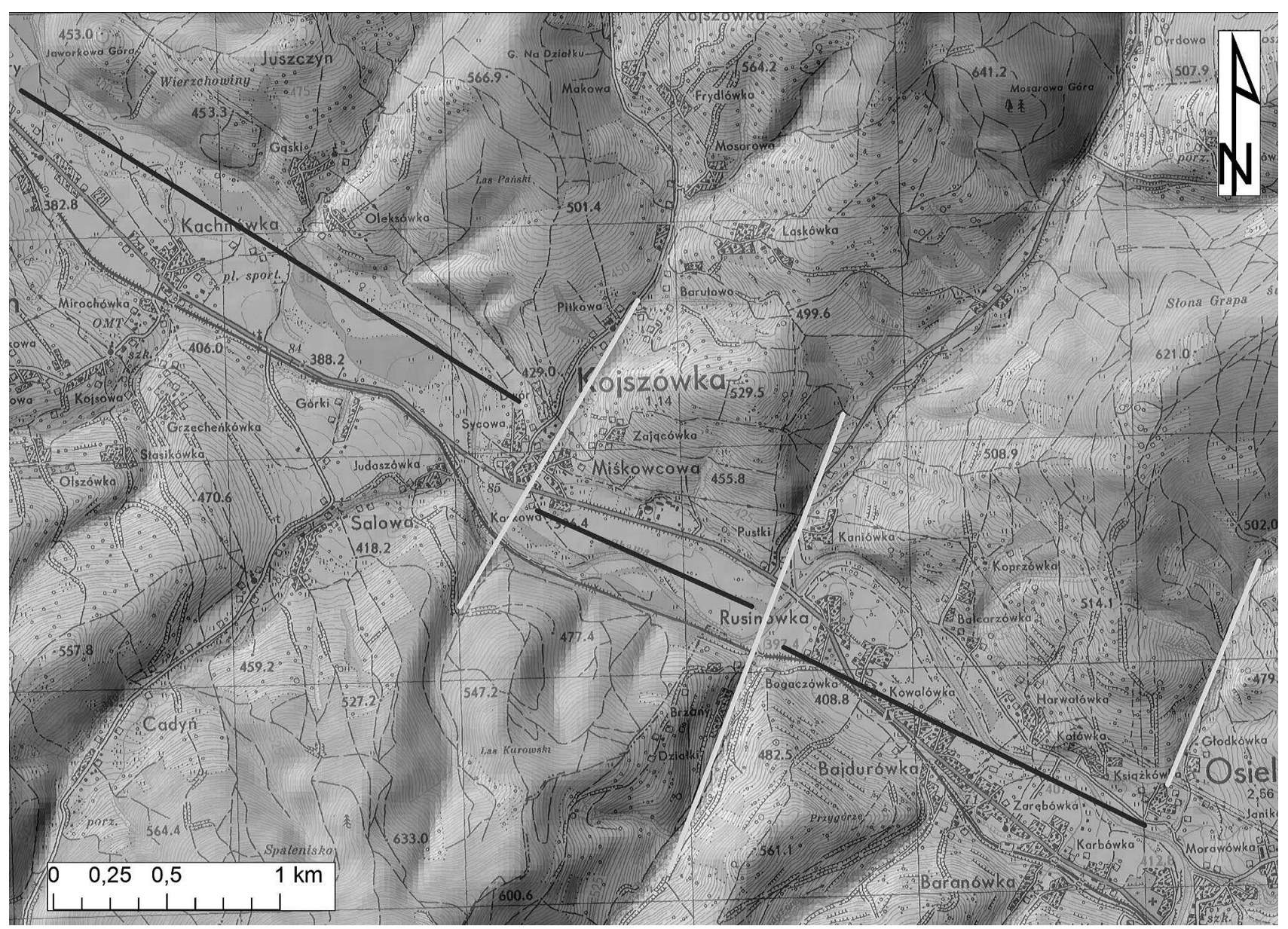

Ryc. 7. Dwie generacje uskoków w zespole uskokowym Kojszówki wyznaczone z zastosowaniem metody lineamentów linia ciemniejsza - uskok starszy, linia jaśniejsza - uskoki młodsze

Fig. 7. Two generation of faults in Kojszówka Fault Group marked with using of the lineaments method dark line - older fault, bright line - younger faults

zadaniem jest zrekonstruowanie różnych elementów geologicznej budowy podłoża na podstawie morfologii terenu. Metody morfometryczne zastosowane na CMW pozwalają na szybkie rozpoznanie morfologii terenu, jej opis oraz wyodrębnienie i klasyfikację poszczególnych form morfologicznych. Metoda lineamentów bazująca na zapisie w morfologii geologicznych struktur podłoża jest bardzo przydatna $\mathrm{w}$ rozpoznawaniu i uzupełnianiu danych pochodzących z kartowania geologicznego, szczególnie jeżeli mamy do czynienia z sytuacją podobną do tej na terenie badań, gdzie starsze utwory podłoża przykryte są młodszą, częściowo je maskującą pokrywą osadową utworów czwartorzędowych. Metoda ta okazała się również bardzo przydatna do lokalizacji stref uskokowych. Niektóre z wyznaczonych lineamentów potwierdziły istnienie uskoków wydzielonych tradycyjnymi metodami kartograficznymi. Metoda lineamentów pozwoliła także na skorygowanie i uściślenie przebiegu uskoków (ryc. 5) oraz umożliwiła rozpoznanie charakteru uskoków, m.in. zespołu uskoków pierzastych w rejonie Wysokiej (ryc. 6), a także wydzielenie nowych uskoków, trudnych do wyznaczenia metodą intersekcyjną. Zaobserwowano też fakt, na który wskazywał wcześniej Zuchiewicz (2010), że lineamenty dają możliwości określania generacji uskoków (ryc. 7), jednak w niniejszej pracy nie podjęto szerzej tej tematyki, ponieważ wykraczało to poza wstępne założenia badawcze projektu. Dodatkowo przeprowadzone analizy pozwoliły na pełniejsze określenie geomorfologicznego charakteru Obniżenia Chabówki-Jordanowa. W jego obrębie wydzielono kilka elementów geomorfologicznych częściowo pokrywających się z klasyfikacją Klimaszewskiego (1972): strefę południową (Pogórze Sieniawskie i Płaskowyż Żeleźnicy), strefę centralną (Kotlina Chabówki, Płaskowyż Naprawy, Obniżenie Jordanowa) oraz strefę północną (południową część Beskidu Średniego i Wyspowego). Metoda ta przyczyniła się także do lepszego rozpoznania tektoniki podłoża, co jest kolejnym krokiem w badaniu i zrozumieniu genezy tektonicznej i geomorfologicznej Obniżenia Chabówki-Jordanowa. Kwestia ta wymaga jednak dalszych uściślających badań.

\section{Podziękowania}

Autor składa serdeczne podziękowania za cenne rady i konsultacje prof. UJ dr. hab. Jackowi Kozakowi, opiekunowi pracy magisterskiej, na bazie której powstało niniejsze opracowanie, a także prof. UJ dr. hab. inż. Markowi Cieszkowskiemu za cenne uwagi dotyczące budowy geologicznej opracowywanego terenu oraz rady w trakcie 
przygotowywania artykułu. Autor dziękuje też anonimowym recenzentom za cenne uwagi i ulepszenia początkowej wersji manuskryptu.

\section{Literatura}

Balon J., German K., Kozak J., Malara H., Widacki W., Ziaja W., 1995. Regiony fizycznogeograficzne. W: J. Warszyńska (red.), Karpaty Polskie przyroda - człowiek i jego działalność. Kraków: 117-130.

Bażyński J., Graniczny M., 1978. Fotolineamenty i ich znaczenie w geologii. Przegląd Geologiczny 5: 288-296.

Burtan F., Szymakowska J., 1964. Szczegółowa Mapa Geologiczna Polski w skali 1:50 000. Arkusz Osielec.

Chodyń R., 2004. Zastosowanie cyfrowego modelu terenu (DEM) w badaniach geologicznych na przykładzie obszaru między Dobczycami a Mszaną Dolną (polskie Karpaty zewnętrzne). Przegląd Geologiczny 45(3): 315-320.

Cieszkowski M., 2007. Stop 2. Chabówka: Structures of the Flysch Carpathians between Nowy Targ and Rabka. Proceedings of the 4th Meeting of the Cental European Tectonic Studies Group/11th Meeting of the Czech Tectonic Studies Group/7th Carpathian tectonic Workshop, Zakopane, Poland, April 19-22. 2006. Geolines 20: 173-176.

Cieszkowski M., Kysiak T., Ślączka A., Wolska A., 2010. Olistoliths of gabro blocks from Osielec (Magura Nappe, Outer Carpathians, Poland). ESSE WECA Conference: Environmental, Structural and Stratigraphical Evolution of the Western Carpathians. Geovestník, Mineralia Slovaca 42(3-4): 507-508.

Cieszkowski M., Golonka J., Waśkowska-Oliwa A., Chrustek M., 2006. Budowa geologiczna rejonu Sucha Beskidzka-Świnna Poręba (polskie Karpaty fliszowe). Geologia 32(2): 155-201.

Cieszkowski M., Golonka J., Krobicki M., Ślączka A., Oszczypko N., Waśkowska A., Wendorff M., 2009. The Northern Carpathian plate tectonic evolutionary stages and origin of olistolithes and olistostromes. Geodinamica Acta 22(1-3): 101-126.

Graniczny M., Mizerski W., 2003. Lineamenty na zdjęciach lotniczych Polski - próba podsumowania. Przegląd Geologiczny 56(6): 474 482.

Jakubowska O., 1987. Związek między elementami strukturalnymi płaszczowiny magurskiej a morfologią górnej części dorzecza Skawy. Czasopismo Geograficzne 48(1): 19-43.
Kasprzak M., Traczyk A., 2010. Geomorfologia granitowej części Karkonoszy. Landform Analysis 13: 33-46.

Klimaszewski M., 1932. W sprawie rozwoju dorzecza Raby i Skawy. Wiadomości Geograficzne 10(2): 21-24.

Klimaszewski M., 1972. Geomorfologia Polski. Polska południowa góry i wyżyny. PWN, Warszawa.

Książkiewicz M., 1971. Geologia Sidziny koło Jordanowa (Karpaty Zachodnie). Roczniki Polskiego Towarzystwa Geologicznego 3-4: 377-391.

Książkiewicz M., 1977. The tectonics of the Carpathians. W: W. Pożaryski (red.), Geology of Poland. Vol. IV. Tectonic. Wydawnictwa Geologiczne, Warszawa: 476-608.

Ollier C., 1987. Tektonika a formy krajobrazu. Wydawnictwa Geologiczne, Warszawa.

Olszewski R., Berezowski T., Świtaj K., 2008. System zarządzania danymi wysokościowymi LPIS, TBD i SMOK zgromadzonymi w PZGIK. Roczniki Geomatyki 6(4): 83-89.

Ozimkowski W., 2008. Lineamenty otoczenia Tatr - porównanie interpretacji DEM i MSS. Przegląd Geologiczny 56(12): 1099-1102.

Paul Z., Ryłko W., 1986. Szczegółowa Mapa Geologiczna Polski w skali 1:50 000 Arkusz Rabka.

Paul Z., Ryłko W., 1987. Objaśnienie do szczegółowej mapy Polski. Arkusz Rabka. Wydawnictwo Geologiczne, Warszawa.

Rehman A., 1895. Karpaty opisane pod względem fizycznogeograficznym. Lwów.

Starkel L., 1969. Odbicie struktury geologicznej w rzeźbie polskich Karpat fliszowych. Studia Geomorphologica Carpatho-Balkanica 20: 61-71.

Starkel L., 1972. Charakterystyka rzeźby Polskich Karpat i jej znaczenie dla gospodarki ludzkiej. Problemy Zagospodarowania Ziem Górskich 10: 75-142.

Starkel L., 1978. First stages of relief transformation of the young uplifted mountains. Studia Geomorphologica Carpatho-Balcanica 12: 45-60.

Wieczorek M., Żyszkowska W., 2011. Geomorfometria - parametry morfometryczne w charakterystyce rzeźby terenu. Polski Przegląd Kartograficzny 43(3): 130- 144.

Wójcik A., Rączkowski W., 1994. Objaśnienie do szczegółowej mapy geologicznej Polski. Arkusz Osielec (1015). Państwowy Instytut Geologiczny, Warszawa.

Zuchiewicz W., 2010. Neotektonika Karpat polskich i Zapadliska Przedkarpackiego. Wydawnictwa AGH, Kraków. 